\title{
TEME DIPLOMSKIH RADOVA NA SMJERU BIBLIOTEKARSTVO STUDIJA INFORMACIJSKIH ZNANOSTI NA FILOZOFSKOM FAKULTETU U ZAGREBU
}

\author{
THE ANALYSIS OF GRADUATION THESES TOPICS \\ OF THE STUDENTS OF LIBRARY SCIENCE AT THE FACULTY \\ OF HUMANITIES AND SOCIAL SCIENCES IN ZAGREB
}

Dorja Mučnjak

Filozofski fakultet, Sveučilište u Zagrebu

dmucnjak@ffzg.hr

Lana Zrnić

Filozofski fakultet, Sveučilište u Zagrebu lzrnic@ffzg.hr

\author{
UDK / UDC 02:[378.2:001.8] \\ Izvorni znanstveni rad / Original scientific paper \\ Primljeno / Received: 19. 9. 2018. \\ Prihvaćeno / Accepted: 21. 11. 2018.
}

\section{Sažetak}

Cilj. Cilj je ovoga rada istražiti na koji su način distribuirane teme diplomskih radova studenata diplomskog studija Informacijskih znanosti, smjer bibliotekarstvo Odsjeka za informacijske i komunikacijske znanosti pri Filozofskom fakultetu Sveučilišta u Zagrebu.

Metodologija. U istraživanju je za prikupljanje podataka korištena metoda kvantitativne analize sadržaja, a za jedinicu analize uzeti su naslovi diplomskih radova (po potrebi uvid u cjeloviti tekst). Tako su iz slobodno dostupnih izvora (institucijski repozitorij i popisi objavljeni u Vjesniku bibliotekara Hrvatske) u razdoblju od lipnja do rujna 2018. prikupljeni podaci za 757 radova objavljenih u razdoblju od 2008. do 2017. godine. Podaci su potom podvrgnuti statističkoj analizi gdje je zastupljenost tema di-

Vjesnik bibliotekara Hrvatske 61, 2(2018), 99-122

ISSN 0507-1925

(C) VBH 2018. 
plomskih radova prikazana grafički, dok su promjene u zastupljenosti pojedinih tema kroz godinu prikazane modelom linearnog trenda.

Rezultati. Najzastupljenije su teme diplomskih radova one o uslugama i aktivnostima knjižnice, dok su teme o metodologiji i obrazovanju u knjižničarstvu potpuno zaobiđene. Podzastupljene su teme iz znanstvene komunikacije te obrade i sustava za označivanje. U istraženom desetogodišnjem razdoblju negativan trend odabira tema utvrđen je u skupini 3 (Nakladništvo, tiskarstvo, povijest knjige), dok u drugim skupinama rezultati nisu pokazali postojanje linearnog trenda.

Analizom naslova utvrđeno je da studenti većinom istražuju tradicionalne teme iz knjižničarstva, dok su istraživanja o netradicionalnim knjižničarskim poslovima i okolini još uvijek podzastupljena.

Ograničenja. U istraživanju su prikupljeni samo podaci iz slobodno dostupnih izvora (institucijski repozitorij i popisi objavljeni u Vjesniku bibliotekara Hrvatske) te je, sukladno tomu, tumačenje rezultata podložno nekim ograničenjima: (a) nije bilo moguće utvrditi zastupljenost tema prema različitim obilježjima studenata, odnosno prema tipu studija (redovni, izvanredni, dodatni, bolonjski, predbolonjski); (b) s obzirom na to da je rađena analiza naslova (iznimno uvidom u sam tekst rada), za pojedine radove nije bilo moguće napraviti precizno određenje teme; (c) radovi su kategorizirani prema glavnoj temi, iako se u pojedinim radovima obrađivalo više tema.

Praktična primjena. Budućim studentima rezultati ovog istraživanja mogu biti polazišna točka pri odabiru istraživačke teme za diplomski rad. Ujedno mogu biti smjerokaz i istraživačima i nastavnicima, odnosno mentorima na diplomskim radovima.

Klasifikacijska shema kreirana za potrebe ovoga rada može biti pomoć voditeljima BDI-zbirki.

Originalnost. Ovo je prvo istraživanje u Hrvatskoj koje se bavi istraživanjem tema diplomskih radova studenata Informacijskih znanosti, smjer bibliotekarstvo na Filozofskom fakultetu u Zagrebu. Također, za potrebe ovoga istraživanja stvorena je nova klasifikacijska shema iz područja knjižničarstva.

Ključne riječi: istraživačke teme, klasifikacijska shema, knjižničarstvo, studenti

\begin{abstract}
Goal. The aim of this paper is to explore the thematic distribution of the graduation theses research topics of the graduate students of the Library Science Programme, the Department of Information and Communication Sciences at the Faculty of Humanities and Social Sciences, University of Zagreb.
\end{abstract}

Methodology. The research method used in the study was the quantitative method of content analysis, and the units of analysis were the titles of the graduation theses (the full 
texts were accessed and consulted if it was necessary). Thus, using the freely accessible sources (the institutional repository and the lists published in the journal Vjesnik bibliotekara Hrvatske), in the period from June to September 2018 the data were collected for the 757 graduation theses published in the period from 2008 to 2017. The research data were then subjected to the statistical analysis where the representation of the topics of the graduation theses was presented in a graphical form, while the changes in the representation of specific topics during each year were presented in a linear trend model.

Results. The most popular graduation theses topics are the library services and activities, while the topics dealing with the methodology and education in librarianship are almost completely omitted. Underrepresented are the topics on scientific communication, cataloguing, and indexing and retrieval systems. In the researched ten-year period, the only negative trend in selecting topics from the Group 3 (publishing, printing, history of books) has been demonstrated, while in other groups the results have not shown the presence of a linear trend.

The content analysis of the graduation theses titles has shown that the students mostly explore traditional librarianship topics, while researching the non-traditional library jobs and environment is still under-represented.

Limitations. Only the data from the freely accessible sources (the institutional repository and the lists published in the journal Vjesnik bibliotekara Hrvatske) were collected in the research, and therefore the interpretation of the results is subject to certain limitations: (a) it was not possible to determine the topics representation according to the different characteristics of students or study programmes (full-time or part-time students, additional study programme, Bologna programme, Pre-Bologna programme, etc.); (b) since the analysis of the topics only was conducted (occasionally the full texts were consulted), for a number of theses it was not possible to determine the topic precisely; (c) the theses were categorized according to the main topic, although some theses dealt with several different topics.

Practical use. For future students, the results of this research can be a starting point for selecting research topics of their graduation theses. At the same time, they can be the direction signs for both researchers and teachers, that is, the mentors of graduation theses.

The classification scheme created for the purpose of this paper may be of assistance to the Library-Documentation-Information (BDI) collection managers.

Originality. This is the first study in Croatia that deals with the contents analysis of the graduation theses topics of the students of the Library Science Programme at the Faculty of Humanities and Social Sciences, University of Zagreb. Furthermore, for the purpose of this research, a new classification scheme in the field of librarianship has been created.

Keywords: Classification scheme, librarianship, research topics, students 


\section{Uvod}

Diplomski rad posljednji je rad koji student izrađuje na diplomskoj razini studija. On bi trebao biti samostalno istraživanje određene teme pod mentorskim vodstvom predmetnog nastavnika. Mentori pokrivaju određena istraživačka područja te iz tih područja studenti mogu birati rad. S obzirom na to da studijski programi teže pokriti veći dio znanstvenog polja ili čak cijelo polje, odnosno granu, pretpostavka je da studenti mogu izabrati temu iz bilo kojeg dijela odabranog znanstvenog polja ili grane.

U Hrvatskoj studijski programi na kojima se obrazuju budući knjižničari imaju različite nazive: u Zagrebu na preddiplomskoj razini studenti upisuju studij Informacijskih znanosti, a na diplomskoj razini studij Informacijskih znanosti, smjer bibliotekarstvo ${ }^{1}$; na Filozofskom fakultetu u Osijeku studenti na obje razine studiraju Informatologiju, a u Zadru Informacijske znanosti. Na sva tri studija programi su usko vezani uz teme iz znanstvene grane knjižničarstva. ${ }^{2}$ Stoga je osnovna premisa ovoga rada da studenti mogu odabrati bilo koju temu iz knjižničarstva za svoj diplomski rad. Da bi se klasificirale istraživačke teme, potrebno je pronaći adekvatnu klasifikacijsku shemu koja će dati pregled svih tema unutar knjižničarstva.

Potreba za klasifikacijom tema kojima se bavi knjižničarstvo bila je povod za istraživanje mnogim autorima. U Hrvatskoj se za klasifikaciju znanja tradicionalno koristi Univerzalna decimalna klasifikacija (UDK), no u svjetskim razmjerima uloženi su napori da se unutar knjižničarstva i informacijskih znanosti načini što preciznija klasifikacija koja bi odražavala recentne promjene u informacijskim i komunikacijskim znanostima.

Cilj je ovoga rada istražiti na koji su način distribuirane teme diplomskih radova studenata Informacijskih znanosti, smjer bibliotekarstvo na Filozofskom fakultetu u Zagrebu. Kako bi se takva distribucija mogla utvrditi, potrebno je ispitati koja klasifikacijska shema najviše odgovara hrvatskoj knjižničarskoj teoriji i praksi.

Rezultati će dati uvid u to koje su teme diplomskih radova studenata bibliotekarstva zastupljenije, a u kojima postoji značajan prostor za daljnja istraživanja.

\footnotetext{
Tijekom devedesetih godina 20. stoljeća došlo je do promjene nazivlja u knjižničarstvu. Dotadašnja izvedenica međunarodnog termina bibliotekar/bibliotekarstvo ostala je u uporabi na studiju Bibliotekarstva na Filozofskom fakultetu u Zagrebu i u naslovu Vjesnika bibliotekara Hrvatske, dok je u struci i zakonodavstvu prevladao naziv knjižničar/knjižničarstvo.

2 Pravilnik o znanstvenim i umjetničkim područjima, poljima i granama. // Narodne novine 118, 2929(2009). [citirano: 2018-08-28] Dostupno na: https://narodne-novine.nn.hr/clanci/sluzbeni/2009_09_118_2929.html.
} 


\section{Pregled literature}

\subsection{Mapiranje informacijskih znanosti i knjižničarstva}

Prema nomenklaturi Pravilnika o znanstvenim i umjetničkim područjima, poljima i granama ${ }^{3}$ (u daljnjem tekstu Pravilnik), polje informacijskih i komunikacijskih znanosti dijeli se na jedanaest grana, od kojih je jedna i knjižničarstvo. Angloamerička literatura knjižničarstvo drži dijelom jedinstvene knjižnične $\mathrm{i}$ informacijske znanosti ${ }^{4}$ (Library and information science), no u međunarodnoj literaturi mogu se naći i termini poput informacijske znanosti (Information science) te knjižnični i informacijski (Library and information studies), odnosno samo informacijski studiji (Information studies) za studije u polju informacijskih znanosti.

U radu će se koristiti prijevodi naziva koje su koristili strani autori. U opisu hrvatskih radova koristit će se terminologija koju su koristili autori. Što se tiče ovoga istraživanja, koristit će se termini iz navedenog Pravilnika: informacijske i komunikacijske znanosti kao polje, odnosno knjižničarstvo kao grana znanosti.

Još 80-ih godina prošloga stoljeća Järvelin i Vakkari ${ }^{5}$ stvaraju klasifikacijsku shemu istraživačkih tema u knjižničnoj i informacijskoj znanosti. Ta klasifikacijska shema donosi 11 skupina (klasa). Prema prijevodu Barbarić, Hebrang Grgić i Horvat ${ }^{6}$ skupine su sljedeće: (1) knjižničarstvo, (2) povijest knjižnica, (3) nakladništvo, tiskarstvo i povijest knjige, (4) obrazovanje, (5) metodologija istraživanja u knjižničarstvu, (6) analiza knjižnične i informacijske znanosti ${ }^{7}$, (7) istraživanja o knjižničnim i informacijskim službama (međuknjižnična posudba, istraživanja korisnika, istraživanja fonda, administracija), (8) istraživanja o pretraživanju informacija (katalogizacija, klasifikacija, indeksiranje, baze podataka, bibliografije), (9) istraživanja o traženju informacija (informacijski kanali i izvori, knjižnične usluge, korištenje informacija), (10) istraživanja o znanstvenoj i profesionalnoj komunikaciji (znanstveno izdavaštvo, citatne analize) i (11) ostale teme.

\footnotetext{
3 Isto.

4 Barbarić,A.; I. Hebrang Grgić; A. Horvat. Metodološki i sadržajni aspekti znanstveno istraživačkih radova objavljenih u Vjesniku bibliotekara Hrvatske od 1998. do 2006. godine. // Vjesnik Bibliotekara Hrvatske 50, 4(2007), str. 2-3. Dostupno i na: http://www.hkdrustvo.hr/vbh-arhiva/ broj/97.

5 Jarvelin, K; P. Vakkari. Content analysis of research articles in library and information science. // Library and Information Science Research 12(1990), 395-421. Citirano prema: Jarvelin, K; P. Vakkari. The evolution of library and information science 1965-1985: a content analysis of journal articles. // Information Processing and Management 29, 1(1993), str. 141-142. DOI: 10.1016/0306-4573(93)90028-C.

6 Barbarić, A.; I. Hebrang Grgić; A. Horvat. Nav. dj., str. 7.

7 Naziv skupine (6) prevele su autorice ovoga istraživanja jer u navedenom članku ta skupina nije bila prevedena.
} 
Ta je klasifikacijska shema široko korištena, uz određena ograničenja i preinake. IFLA ju je koristila u usporedbi nacionalnih istraživačkih trendova ${ }^{8}$, uz napomenu da shemi nedostaju detaljnije definicije za skupine (klase), što može dovesti do različitih shvaćanja istog pojma. No bez obzira na navedeno, shema je pružila unificirani pregled s mogućnošću usporedbe istraživanja iz knjižnične i informacijske znanosti u nekoliko zemalja širom svijeta. U već navedenom istraživanju Barbarić, Hebrang Grgić i Horvat ${ }^{9}$ koriste tu shemu za istraživanje metodoloških i sadržajnih aspekata istraživačkih radova u Vjesniku bibliotekara Hrvatske (VBH). $\mathrm{U}$ tom radu donose vrijedan prijevod sheme, ali i kritiku u kojoj navode da je ona nastala 80 -ih godina prošloga stoljeća. U istraživanju iz 2014. godine ${ }^{10}$ sami autori klasifikacijske sheme ponovno ju koriste, ali u ponešto izmijenjenom izdanju, prilagođenom recentnom razvoju informacijskih znanosti.

Početkom 21. stoljeća Wilson ${ }^{11}$ predlaže model s četiri temeljne skupine: (1) informacijski sadržaj, (2) informacijski sistemi, (3) ljudi i (4) organizacije koje se međusobno preklapaju. Taj model funkcionira prvenstveno za razdiobu kolegija studijskih programa.

Godinu kasnije Crumley i Koufogiannakis ${ }^{12}$ objavljuju rad u kojem istražuju koje su teme važne za razvoj knjižničarstva utemeljenog na dokazima (engl. evidence-based librarianship) te zaključuju: (1) informacijska služba/upiti, (2) edukacija, (3) zbirke, (4) upravljanje, (5) pristup informacijama i pretraživanje te (6) marketing/promocija. Ta shema, evidentno, nije pogodna za klasifikaciju cijelog polja knjižničarstva jer se bavi isključivo temama koje su bitne za donošenje odluka u svakodnevnom poslovanju knjižnica. Upravo su to autorice pokazale u istraživanju iz 2004. godine ${ }^{13}$ u kojem su sadržajnom analizom članaka iz knjižnične i informacijske znanosti pokazale da se dio literature bavi poviješću knjižnica i knjižničarstva, no one kategoriju odbacuju kao irelevantnu za knjižničarstvo utemeljeno na dokazima. No dodaju kategoriju koja se odnosi na strukovna pitanja

8 Rochester, M.; P. Vakkari. International Library and information science research: a comparison of national trends. [Haag] : International Federation of Library Associations and Institutions, cop. 2003. (IFLA professional reports ; nr.82). [citirano: 2018-08-30]. Dostupno na: https://www. ifla.org/publications/ifla-professional-reports-82.

9 Barbarić, A.; I. Hebrang Grgić; A. Horvat. Nav. dj., str. 7.

10 Tuomaala, O.; K. Järvelin; P. Vakkari. Evolution of Library And information science, 19652005: content analysis of journal articles. // Journal of the Association for Information Science and Technology 65, 7(2014), 1446-1462. DOI: https://doi.org/10.1002/asi.23034.

11 Wilson, T.D. Mapping the curriculum in information studies. //New Library World 102, 11/12(2001), str. 436-437. DOI: https://doi.org/10.1108/03074800110411875.

12 Crumley, E.; D. Koufogiannakis. Developing evidence-based librarianship: practical steps for implemantation. // Health Information and Libraries Journal 19, 2(2002), str. 63-64. DOI: https:// doi.org/10.1046/j.1471-1842.2002.00372.x.

13 Koufogiannakis, D.; L. Slater; E. Crumley. A content analysis of librarianship research. // Journal of Information Science 30, 3(2004), str. 232-235. DOI: 10.1177/0165551504044668. 
(akreditacija, kompetencije, imidž...). Na kraju, promišljaju i o spajanju dviju kategorija: upravljanja i marketinga/promocije.

Godine 2007. Blessigner i Frasier ${ }^{14}$ analiziraju trendove u objavljivanju i citiranju u knjižničnoj i informacijskoj znanosti u razdoblju od 1994. do 2004. godine te klasificiraju teme u 5 većih skupina: (1) knjižnične procedure i službe, (2) istraživanja u knjižničnoj i informacijskoj znanosti/korisnici, (3) knjižničarska, odnosno informacijska profesija, (4) tehnologija i (5) izdavaštvo.

Iste godine Zins ${ }^{15}$ izrađuje sveobuhvatnu studiju mapiranja znanja informacijskih znanosti, što rezultira mapom znanja od 10 skupina: (1) temelji znanosti, (2) izvori, (3) djelatnici, (4), sadržaj, (5) primjena, (6) postupci i procedure, (7) tehnologija, (8) okruženje, (9) organizacije i (10) korisnici. Ta je shema primjenjiva na sve grane informacijskih znanosti. Tijekom iste studije Zins ${ }^{16}$ provodi panel-diskusiju s 28 stručnjaka iz informacijskih znanosti tijekom koje svaki od njih donosi svoju klasifikacijsku shemu informacijskih znanosti. Jednu od njih mnogi autori koriste kao temelj za svoja istraživanja. Riječ je o shemi Baruchson-Arbib ${ }^{17}$ koju koristi Prebor ${ }^{18} \mathrm{u}$ sadržajnoj analizi magistarskih radova i doktorskih disertacija te Aharoni u svojoj sadržajnoj analizi članaka deset najistaknutijih časopisa iz knjižnične i informacijske znanosti.

Recentnu shemu s deset glavnih skupina istraživačkih tema iz područja knjižnične i informacijske znanosti predlaže The Association for Library and Information Science Education (ALISE) ${ }^{19}$ : (1) razvoj/principi knjižnične i informacijske znanosti, (2) organizacija informacija, (3) edukacija, (4) informacijski sustavi i pretraživanje, (5) razvoj zbirki, (6) vrste knjižnica i pružatelja informacijskih usluga, (7) korisničke usluge, (8) upravljanje/poslovanje, (9) informatika i (10) školske knjižnice. S obzirom na to da je kreirana na podacima iz Kanade i SAD-a, za svoja istraživanja koriste ju uglavnom istraživači iz tih zemalja. ${ }^{20}$ Jedna od

14 Blessinger, K.; M. Fraiser. Analysis of a decade in library literature: 1994-2004. // College \& Research Libraries 68, 2(2007), str. 158. DOI: 10.5860/crl.68.2.155.

15 Zins, C. Knowledge mapping research. // Journal of the American Society for Information Science and Technology 58, 4(2007), str. 528-531. DOI: 10.1002/asi.v58:4.

16 Zins, C. Classification schemes of Information science: twenty-eight scholars map the field. // Journal of the American Society for Information Science and Technology 58, 5(2007), 645-672. DOI: https://doi.org/10.1002/asi.20506.

17 Isto, str. 647.

18 Prebor. G. Information science - facing social and ethical challenges: analysis of masters' theses and doctoral dissertations over the past five years (2002-2006) in Information science departments worldwide. // Journal of Information, Communication and Ethics in Society 5, 2/3(2007), 253-269. DOI: 10.1108/14779960710837687.

19 Yi, K.; R. Turner. The current landscape of the school librarianship curricula in USA. // Journal of Education for Library and Information Science 55, 4(2014), str. 318-319. [citirano: 2018-0830]. Dostupno na: https://eric.ed.gov/?id=EJ1074323.

20 Paul-Hus, A.; P. Mongeon; F. Shu. Portraying the landscape of Canadian library and information science research. // Canadian Journal of Information and Library Science 40, 4(2016), 
primjedbi koje se često stavljaju na teret toj klasifikacijskoj shemi jest ta da je ona napravljena prema istraživačkim i obrazovnim temama fakultetskog osoblja kako su ih oni sami opisivali i navodili. Druga je ta što sama klasifikacijska shema više naginje knjižničnoj nego drugim informacijskim znanostima. ${ }^{21}$

Na kraju, važno je napomenuti da se u Hrvatskoj kao univerzalna klasifikacija znanja tradicionalno koristi UDK. Tu su praksu Bačić i Majstorović22 iskoristile u svojoj kvantitativnoj raščlambi članaka iz VBH. Osnovu za utvrđivanje tematskih skupina preuzele su iz UDK, no neke su skupine preinačile za potrebe rada.

\subsection{Dosadašnja istraživanja}

U bibliometrijskoj analizi magistarskih radova studenata Postdiplomskog studija informacijskih znanosti Sveučilišta u Zagrebu u razdoblju od 1961. do $1984 .{ }^{23}$ cilj je bio kvantitativnim indikatorima dati uvid u područja pokrivena magistarskim radovima. Zaključeno je da su analiza i opis informacijskih ustrojbenih jedinica (knjižnice, arhivi, muzeji, informacijske i dokumentacijske službe) najčešća tema analiziranih disertacija, čak $45 \%$ njih, i to u sva četiri područja. Odabir, nabava, identifikacija i očuvanje informacijskih materijala također su bili zastupljeni u svim područjima, ali najviše u bibliotekarstvu, muzeologiji i arhivistici, a u informacijskim znanostima manje. Teme pohrane, pretraživanja i interpretacije informacijskog sadržaja zastupljene su u svim disciplinama, ali opet najviše u bibliotekarstvu. Informacijska se tehnologija pojavljivala skoro samo u tezama iz informacijskih znanosti. Ostali su rezultati pokazali interdisciplinarnu i multidisciplinarnu prirodu informacijskih znanosti.

U istraživanju iz 1988. godine Vukasović ${ }^{24}$ se bavi temama doktorskih disertacija iz bibliotekarstva i informacijskih znanosti obranjenih na sveučilištima u bivšoj Jugoslaviji u razdoblju od 1972. do kraja 1985. U tom razdoblju obranjeno je 30 disertacija iz područja informacijskih znanosti, a dominiraju teme iz povi-

332-346. [citirano: 2018-08-30]. Dostupno na: https://muse.jhu.edu/article/649274.

${ }^{21}$ Shu, F.; J. Beheshti. The landscape of LIS research and teaching area: iSchools versus non-iSchools in North America. // iConference Proceedings, 2016. Str. 3. DOI: 10.9776/16203.

${ }^{22}$ Bačić, M.; Z. Majstorović. Kvantitativna raščlamba članaka objavljenih u Vjesniku bibliotekara Hrvatske. // Vjesnik Bibliotekara Hrvatske 50, 4(2007), 15-25. Dostupno i na: https://hrcak. srce.hr/85586 [citirano: 2018-08-30].

${ }^{23}$ Tuđman, M.; M. Milas; N. Tudor-Šilović; D. Boras. Bibliometric analysis of master theses in Information sciences (postgraduate studies in Librarianship, Archivistics, Museology and Information sciences, 1961-1964, Zagreb, Yugoslavia). // Education for Information 3, 4(1985), 291-306. DOI: 10.3233/EFI-1985-3404.

24 Vukasović, K. Teme doktorskih disertacija iz bibliotekarstva i informacionih nauka objedinjene na univerzitetima u Jugoslaviji. // Naučna istraživanja u bibliotekarstvu: zbornik radova s Trećeg jugoslavenskog interkatedarskog skupa nastavnika bibliotekarstva. Beograd: Filološki fakultet, 1988. Str. 37-44. 
jesnog aspekta razvoja knjižničarstva te sustava pojedinih područja. Iz bibliotekarstva je obranjeno 10 disertacija, a 7 ih se odnosi na povijest knjižničarstva ili pisma, dok 3 razmatraju aktualne knjižničarske probleme (vezane uz poslovanje knjižnica ili korisnike usluga).

Od recentnijih bibliometrijskih istraživanja diplomskih radova svakako treba navesti ono Hebrang Grgić i Barbarić2 ${ }^{25}$ u kojem je analizirano 78 diplomskih radova, odnosno 1717 referenci. Gledao se broj referenci po radu, vrsta izvora, tip izvora, jezik reference, broj autora te starost izvora, a rezultati mogu biti velika pomoć studentima, nastavnicima i knjižničarima.

Navedena istraživanja bila su provedena u Hrvatskoj i bivšoj Jugoslaviji te su obuhvaćala podatke iz nekoliko desetljeća. Uz prijašnja istraživanja koja smo navele, smatramo da je zanimljivo spomenuti i indonezijsko istraživanje završnih radova studenata knjižnične i informacijske znanosti iz 2018. godine. ${ }^{26}$ Iako je ovo istraživanje provedeno $u$ Indoneziji, i to na završnim, a ne na diplomskim radovima, držimo da bi rezultati mogli biti općenito zanimljivi kao pokazatelj interesa studenata. Na uzorku od 1436 naslova završnih radova zaključeno je da su teme vezane uz knjižnične usluge i izvore, informacijske usluge, informacijske sustave te informacijsko društvo one koje se najčešće ponavljaju. Ostale su teme, vezane npr. uz informacijske tehnologije, bibliometriju, pretraživanje i dijeljenje informacija, manje zastupljene.

\section{Istraživanje}

Cilj ovog istraživanja bio je da se utvrde teme diplomskih radova studenata bibliotekarstva na Odsjeku za informacijske i komunikacijske znanosti pri Filozofskom fakultetu Sveučilišta u Zagrebu u razdoblju od 2008. do 2017. godine i njihova zastupljenost.

Istraživačka pitanja koja iz navedenog proizlaze jesu:

1. Kakva je distribucija diplomskih radova po temama?

2. Kakav je trend obrađivanja tema kroz desetogodišnje razdoblje?

25 Hebrang Grgić, I. ; A. Barbarić. LIS student's diploma theses as digital documents: citation analysis. // La médiation numérique : renouvellement et diversification des pratiques / ed. by Boustany, J.; E. Broudoux ; G. Chartron. Bruxelles: De Boeck, 2014. Str. 183-190.

26 Anna, N. E. V.; E. F. Mannan; D. P. Srirahayu; F. Mutiai. Library and information (LIS) research topics in Indonesia from 2006 to 2017. // Library Philosophy and Practice. 2018. [citirano: 2018-08-30]. Dostupno na: http://digitalcommons.unl.edu/libphilprac/1773/. 


\subsection{Metodologija}

\subsubsection{Uzorak}

Istraživanje je provedeno na uzorku diplomskih radova studenata koji su diplomirali na studiju Bibliotekarstva na Odsjeku za informacijske i komunikacijske znanosti pri Filozofskom fakultetu Sveučilišta u Zagrebu u razdoblju od 2008. do 2017. godine. U akad. godini 2005./2006. uvedeni su studijski programi prema pravilima i zahtjevima Bolonjske reforme. S obzirom na to da preddiplomski i diplomski studij zajedno traju 5 godina te da su prvi studenti informacijskih znanosti smjer bibliotekarstvo mogli diplomirati tek 2010. godine, u istraživanju su uzeti u obzir i diplomski radovi studenata koji su upisali tzv. predbolonjski program, odnosno uzeti su u obzir diplomski radovi studenata koji su studirali:

1. Dodiplomski studij informatologije, smjer bibliotekarstvo (predbolonjski studij) - u trajanju od četiri godine

2. Dodiplomski studij bibliotekarstva (predbolonjski studij) - u trajanju od dvije godine (dodatni studij) ${ }^{27}$

3. Izvanredni studij bibliotekarstva (predbolonjski studij) - u trajanju od dvije godine

4. Diplomski studij informacijskih znanosti, smjer bibliotekarstvo (redovni način studiranja) - u trajanju od dvije godine ${ }^{28}$

5. Izvanredni studij informacijskih znanosti, smjer bibliotekarstvo ${ }^{29}$ (izvanredni način studiranja) - u trajanju od dvije godine.

Važno je napomenuti da i redovni i izvanredni studij bibliotekarstva prate jednak studijski program, uz razliku u načinu provedbe programa - redovni, odnosno izvanredni način studiranja. Analizirani su diplomski radovi nastali tijekom desetogodišnjeg razdoblja jer je pretpostavka da je takav vremenski kontinuum dovoljno dug za utvrđivanje dijakronijskih trendova u odabiru tema diplomskih radova.

Prikupljeni su podaci o ukupno 757 diplomskih radova.

Podaci o naslovima diplomskih radova i godini diplomiranja preuzeti su iz javno dostupnih izvora: iz javno objavljenih popisa diplomiranih studenata gore na-

\footnotetext{
27 Studij koji su, prije uvođenja Bolonjske reforme, upisivali studenti koji su studirali neki drugi studij, a željeli su se dodatno obrazovati u knjižničarstvu.

28 ECTS informacijski paket za akademsku godinu 2018/2019. [citirano: 2018-10-30]. Dostupno na: http://theta.ffzg.hr/ECTS/Studij/Lista?razinaStudijaID=4.

29 Natječaj/upis na izvanredni studij informacijskih znanosti (bibliotekarstvo). [citirano: 201810-30]. Dostupno na: http://inf.ffzg.unizg.hr/index.php/hr/studij/izvanredni-studij-novi/natjecaj-upis.
} 
vedenih studija u Vjesniku bibliotekara Hrvatske ${ }^{30}$ te iz Repozitorija ${ }^{31}$ Filozofskog fakulteta Sveučilišta u Zagrebu u kojem je od akad. god. 2013./2014. obvezna pohrana diplomskih radova. Iz Repozitorija su preuzeti podaci svih diplomskih radova iz područja Informacijske i komunikacijske znanosti s oznakom Bibliotekarstvo te podaci diplomskih radova s oznakama Knjiga i nakladništvo i Organizacija znanja, koje su povezane s istoimenim katedrama na Odsjeku za informacijske i komunikacijske znanosti pri Filozofskom fakultetu u Zagrebu na kojima djeluju nastavnici koji sudjeluju u obrazovanju knjižničara, a koji su ujedno i mentori na popisanim diplomskim radovima.

Ostavljamo mogućnost da postoji određeni broj diplomskih radova čiji podaci nisu javno dostupni, ali pretpostavljamo da je taj broj zanemariv te da ne utječe na krajnji rezultat istraživanja.

\subsubsection{Provedba istraživanja}

Istraživanje je provedeno od lipnja do rujna 2018. godine.

Za prikupljanje podataka korištena je metoda analize sadržaja, za jedinicu analize uzeti su naslovi diplomskih radova, dok je za analizu podataka korištena kvantitativna analiza frekvencija tema.

30 Barbarić, A. Popis diplomiranih studenata na Dodiplomskom studiju bibliotekarstva Filozofskog fakulteta u Zagrebu 2007.-2008. // Vjesnik bibliotekara Hrvatske 51, 1-4(2008), 287-289. Dostupno i na: https://hrcak.srce.hr/85679 [citirano: 2018-08-30]; Barbarić, A. Popis diplomiranih studenata na Izvanrednom studiju bibliotekarstva Filozofskog fakulteta u Zagrebu 2007.2008. // Vjesnik bibliotekara Hrvatske 51, 1-4(2008), 292-297. Dostupno i na: https://hrcak.srce. hr/85681 [citirano: 2018-08-30]; Barbarić, A. Popis obranjenih diplomskih radnji na Studiju informatologije, smjer bibliotekarstvo Filozofskog fakulteta u Zagrebu 2007.-2008. // Vjesnik bibliotekara Hrvatske 51, 1-4(2008), 290-291. Dostupno i na: https://hrcak.srce.hr/85680 [citirano: 2018-08-30]; Hebrang Grgić, I. Popis diplomiranih studenata na studiju bibliotekarstva na Filozofskom fakultetu u Zagrebu. // Vjesnik bibliotekara Hrvatske 53, 3-4(2010), 243-247. Dostupno i na: https://hrcak.srce.hr/80609 [citirano: 2018-08-30]; Hebrang Grgić, I. Popis obranjenih diplomskih radova na dodiplomskom studiju bibliotekarstva, studiju informatologije (smjer bibliotekarstvo) i izvanrednom studiju bibliotekarstva na Filozofskom fakultetu u Zagrebu 2011. godine. // Vjesnik bibliotekara Hrvatske 56, 1-2(2013), 386-392. Dostupno i na: https://hrcak. srce.hr/115670 [citirano: 2018-08-30]; Tot, M.; I. Hebrang Grgić; A. Barbarić. Popis studenata koji su obranili diplomski rad na diplomskom studiju informacijskih znanosti, smjer bibliotekarstvo na Odsjeku za informacijske i komunikacijske znanosti Filozofskog fakulteta Sveučilišta u Zagrebu (reformirani, tzv. bolonjski studij, redovni i izvanredni način studiranja) 2013. godine. // Vjesnik Bibliotekara Hrvatske 58, 1-2(2015), 440-445. Dostupno i na: https://hrcak.srce. hr/143661 [citirano: 2018-08-30]; Tot; M.; I. Hebrang Grgić; A. Barbarić. Popis studenata koji su obranili diplomski rad na diplomskom studiju informacijskih znanosti, smjer bibliotekarstvo na Odsjeku za informacijske i komunikacijske znanosti Filozofskog fakulteta Sveučilišta u Zagrebu (reformirani, tzv. bolonjski studij, redovni i izvanredni način studiranja) 2014. godine. // Vjesnik Bibliotekara Hrvatske 58, 1-2(2015), 446-450. Dostupno i na: https://hrcak.srce.hr/143662 [citirano: 2018-08-30].

31 Repozitorij Filozofskog fakulteta u Zagrebu. [citirano: 2018-11-21]. Dostupno na http://darhiv.ffzg.unizg.hr/. 
Za svaki diplomski rad izlučeni su, kao relevantni, podaci o naslovu i godini obrane rada. Analiza sadržaja rađena je prema naslovu rada i, ukoliko iz naslova nije bilo moguće nedvosmisleno odrediti temu, uvidom u sam diplomski rad.

Klasifikacijska shema koja je korištena tijekom ovoga istraživanja temelj nalazi u shemi Järvelina i Vakkarija. ${ }^{32}$ Ta je shema preuzeta jer je već korištena u hrvatskoj znanstvenoj produkciji ${ }^{33}$ za analizu sadržaja članaka iz grane knjižničarstva te je od svih navedenih shema u prethodnom poglavlju bila naizgled najprikladnija.

Ipak, prilikom testnog kodiranja prvih nekoliko desetaka radova klasifikacijska je shema znatno izmijenjena iz sljedećih razloga:

- klasifikacijska shema Järvelina i Vakkarija zastarjela je te ne uzima u obzir recentni razvoj informacijskih i komunikacijskih znanosti te knjižničarstva

- skupine nisu jasno podijeljene i neke teme mogu se, na temelju različitih tradicija, svrstati u više različitih skupina

- skupine nemaju jasno odijeljen aspekt koji se istražuje (npr. interno poslovanje u istoj je kategoriji kao i aktivnosti za korisnike...).

Stoga je u ovome istraživanju korištena shema verificirana prilikom testnog kodiranja (tablica 1).

Tablica 1. Klasifikacijska shema

\begin{tabular}{|l|l|l|}
\hline Skupina & Podskupina & Naziv \\
\hline 1. & & Teorija knjižničarstva \\
\hline 2. & & $\begin{array}{l}\text { Povijest knjižnica, povijesni razvoj knjižnica, pojedine } \\
\text { knjižnice općenito }\end{array}$ \\
\hline 3. & & Nakladništvo, tiskarstvo, povijest knjige \\
\hline 4. & & Obrazovanje i stalno stručno usavršavanje \\
\hline 5. & & Metodologija istraživanja u knjižničarstvu \\
\hline 6. & & Poslovanje i upravljanje \\
\hline & 6.1. & Prostor, zgrade, oprema \\
\hline & 6.2. & Marketing \\
\hline & 6.3. & Vrednovanje, planiranje \\
\hline & 6.4. & Djelatnici (stalno stručno usavršavanje, stavovi) \\
\hline & 6.5. & Ostalo \\
\hline
\end{tabular}

32 Järvelin, K; P. Vakkari. Content analysis. Nav. dj.

33 Barbarić, A.; I. Hebrang Grgić; A. Horvat. Nav. dj. 


\begin{tabular}{|c|c|c|}
\hline Skupina & Podskupina & Naziv \\
\hline \multicolumn{2}{|l|}{7.} & Korisničke službe i aktivnosti knjižnica \\
\hline & 7.1. & Posudba i dostava dokumenata \\
\hline & 7.2 . & Izvori (zbirke) \\
\hline & 7.3. & Informacijska služba i usluge \\
\hline & 7.4. & Poduka korisnika, informacijska pismenost \\
\hline & 7.5 . & Ostale aktivnosti \\
\hline \multicolumn{2}{|l|}{8.} & Obrada, sustavi za označivanje i pretraživanje \\
\hline & 8.1. & Metapodaci, katalozi, baze podataka \\
\hline & 8.2. & Formalna obradba \\
\hline & 8.3 . & Stručna i predmetna obrada, označivanje \\
\hline \multicolumn{2}{|l|}{9.} & Korisničke potrebe i informacijsko ponašanje \\
\hline & 9.1. & $\begin{array}{l}\text { Korištenje informacijskih kanala i izvora (fokus na kanale } \\
\text { i izvore) }\end{array}$ \\
\hline & 9.2. & $\begin{array}{l}\text { Korištenje knjižničnih usluga (bez kanala i izvora) - fo- } \\
\text { kus na usluge }\end{array}$ \\
\hline & 9.3 . & Informacijske potrebe korisnika \\
\hline & 9.4. & Informacijsko ponašanje (fokus na korisnike) \\
\hline \multicolumn{2}{|l|}{10.} & Znanstvena i profesionalna komunikacija \\
\hline & 10.1. & Znanstveno izdavaštvo \\
\hline & 10.2 & Bibliometrija i scientometrija \\
\hline & 10.3 . & Ostali aspekti \\
\hline \multicolumn{2}{|l|}{11.} & Ostale teme \\
\hline
\end{tabular}

Skupina 1. Teorija knjižničarstva. Prvoj skupini pripadaju istraživanja koje se tiču teorije i temelja knjižničarstva (teorije, pravni propisi, slobodan pristup informacijama, etika...).

Skupina 2. Povijest knjižnica, povijesni razvoj knjižnica, pojedine knjižnice općenito. Ovoj skupini pripadaju radovi koji istražuju povijest i razvoj knjižnica i knjižničnih sustava te oni koji daju cjelokupni prikaz jedne ili više knjižnica. Ako su radovi bili na temu pojedinih segmenata poslovanja, odnosno pojedinih usluga ili aktivnosti, bili su kategorizirani u skupinama 6 i 7. 
Skupina 3. Nakladništvo, tiskarstvo, povijest knjige. Radovi koji istražuju nakladništvo i tiskarstvo (elektroničko i tradicionalno), knjigu i povijest knjige potpadaju u ovu skupinu, no tu ne spadaju radovi koji govore o znanstvenoj komunikaciji. S obzirom na to da neki radovi obrađuju i temu povijesti knjige i povijesti knjižnica, odabrana je tema koja je dominantna u određenom radu (odlučeno uvidom u rad).

Skupina 4. Obrazovanje i stalno stručno usavršavanje. Ova skupina okuplja radove o kvaliteti studijskih programa, kompetencijama, važnosti stalnog stručnog usavršavanja, a sve s teorijskog gledišta.

Skupina 5. Metodologija istraživanja u knjižničarstvu. U ovu skupinu spadaju radovi koji se bave samom metodologijom istraživanja u knjižničarstvu, poput načina prikupljanja podataka, kategorizacije radova...

Skupina 6. Poslovanje i upravljanje odnosi se na unutarnje poslovanje knjižnica koje tek posredno ima veze s korisnicima - ovdje spada upravljanje resursima, procedure, marketing i djelatnici (obrazovanje djelatnika, ali iz praktične perspektive, a ne teorijske...).

Skupina 7. Korisničke službe i aktivnosti knjižnica. U ovoj su skupini okupljene teme koje se tiču usluga i aktivnosti koje knjižnice nude svojim korisnicima (izvori, posudba, informacijska služba...).

Skupina 8. Obrada, sustavi za označivanje i pretraživanje. Okuplja teme o obradi i pretraživanju informacija s gledišta podataka i metapodataka (katalozi, formalna, sadržajna i predmetna obrada, sustavi za označivanje...).

Skupina 9. Korisničke potrebe i informacijsko ponašanje. U ovoj skupini naglasak je stavljen na potrebe i ponašanje korisnika iz njihove perspektive. Tu se nalaze istraživanja korisnika.

Skupina 10. Znanstvena i profesionalna komunikacija. Ova skupina odnosi se na radove koji obrađuju teme iz znanstvene komunikacije, uključujući bibliometrijska i scientometrijska istraživanja.

Skupina 11. Ostale teme. Okuplja sve ostale teme koje mogu biti iz drugih grana informacijskih znanosti ili pak drugih znanstvenih područja ili polja.

Klase od 6.0. do 10.0. dijele se na podskupine kako bi razdioba tema bila što jasnija. Ako neko istraživanje pokriva više podskupina ili sve podskupine, moguće je koristiti višu decimalnu oznaku (npr. istraživanje govori o svim uslugama knjižnice, pa se koristi oznaka 7., a ako istraživanje govori o informacijskoj službi kao jednoj od usluga knjižnice, koristi se oznaka 7.3.).

Za potrebe ovog istraživanja naslovima radova pridodana je isključivo jedna oznaka (jedna skupina ili podskupina). Ako je neki rad imao više tema, pridodana mu je oznaka za glavnu temu rada. Svaki rad označile su obje autorice ovog istraživanja, s time da je o neujednačenim oznakama donesena zajednička odluka kojoj 
skupini ili podskupini rad pripada. Podudarnost oznaka bila je u $93 \%$ slučajeva, dok je 7 posto radova bilo različito označeno te se o njima odlučilo zajednički.

\subsection{Rezultati i rasprava}

Istraživanjem su prikupljeni podaci o 757 diplomskih radova u razdoblju od 2008. do 2017. godine.

U odabranom desetogodišnjem razdoblju broj diplomskih radova po godinama se razlikuje. Prosječan broj radova po godini je 75,7. „Najplodnija“ godina bila je 2011. sa 119 diplomskih radova, a najmanje diplomskih radova (50) bilo je obranjeno 2015. godine. Godina 2010. broji 90 radova, a odmah zatim slijede 2008. s 89 radova i 2013. s 87 radova. Godina 2014. donosi $71 \mathrm{rad}$, a 2012. godina 67 radova. U 2009. nalazimo 62 rada, a po jedan manje (61) u 2016. i 2017. godini. Na slici 1 vidljiva je raspodjela broja diplomskih radova po godinama.

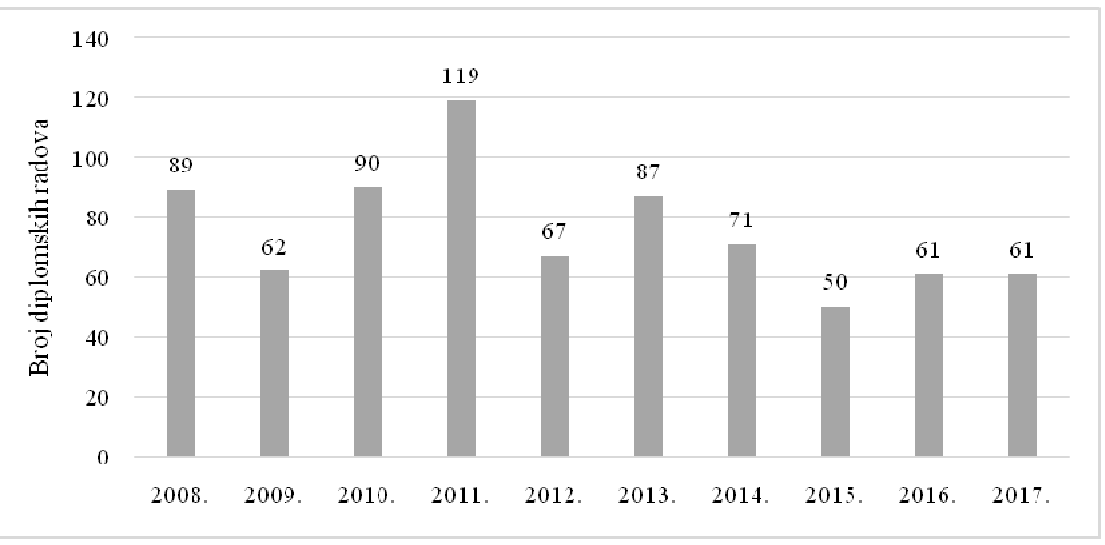

Slika 1. Broj diplomskih radova po godinama

Distribucija tema po skupinama nije jednaka. Kroz desetogodišnje razdoblje, najviše radova (339, odn. 44,8 \%) obrađivalo je teme iz skupine 7 (Korisničke službe i aktivnosti knjižnica). Po broju diplomskih radova slijedi skupina 2 (Povijest knjižnica, razvoj, knjižnice) s 99 radova (13,1\%), zatim skupina 9 (Korisničke potrebe i informacijsko ponašanje) sa 73 rada $(9,6 \%$ ), skupina 6 (Poslovanje i upravljanje) sa 72 rada $(9,5 \%)$, skupina 3 (Nakladništvo, tiskarstvo, povijest knjige) s 59 radova $(7,8 \%$ ), skupina 1 (Teorija knjižničarstva) s 46 radova $(6,1)$, skupina 8 (Obrada, sustavi za označivanje i pretraživanje) s 36 radova $(4,8 \%)$ i skupina 11 (Ostale teme) s 26 radova (3,4 \%). Manje od deset radova $(0,9 \%)$ bilo je u skupini 10 (Znanstvena i profesionalna komunikacija). U skupinama 4 (Obrazovanje i stalno stručno usavršavanje) i 5 (Metodologija istraživanja u knjižničarstvu) nije evidentiran nijedan rad. Na slici 2 grafički je prikazana raspodjela ukupnog broja diplomskih radova po skupinama. 


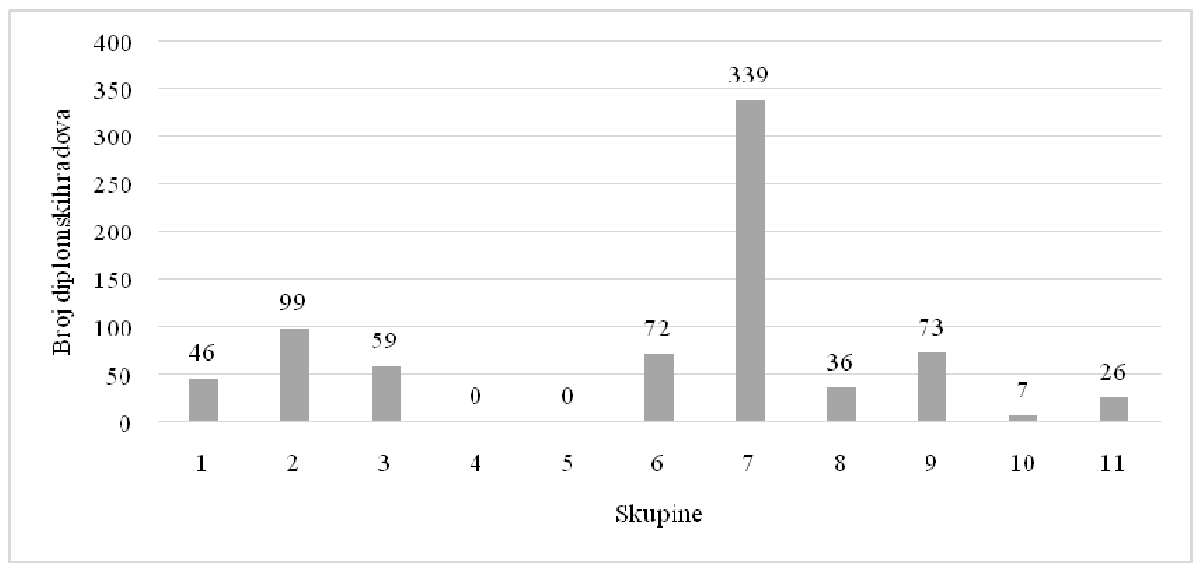

Slika 2. Ukupan broj diplomskih radova po skupinama, 2008.-2017.

Najveći udio radova u skupini sedam možemo tumačiti sljedećim činjenicama: s obzirom na to da dio diplomiranih studenata dolazi iz radnog okruženja (Izvanredni studij, odnosno studij uz rad), može se pretpostaviti da velik dio diplomskih radova u kojima se predstavljaju usluge ili aktivnosti knjižnica pišu studenti koji već rade u knjižnicama jer im je pristup potrebnim informacijama jednostavniji.

U skupinama 4 (Obrazovanje i stalno stručno usavršavanje) i 5 (Metodologija istraživanja u knjižničarstvu) ne nalazimo nijedan rad. Ti podaci mogu se tumačiti time što se u tim dvjema skupinama nalaze teme koje mogu bolje obraditi stručnjaci s više profesionalnog i znanstvenog iskustva, dok studenti vjerojatno smatraju da ne vladaju u dovoljnoj mjeri teorijskim temeljima i nemaju dovoljno iskusan pogled na te dvije tematske skupine.

$\mathrm{U}$ istraženom desetogodišnjem razdoblju utvrđen je negativan trend odabira tema iz skupine 3 (Nakladništvo, tiskarstvo, povijest knjige), dok u drugim skupinama rezultati nisu pokazali postojanje linearnog trenda. $\mathrm{S}$ obzirom na to da $\mathrm{u}$ tu skupinu nisu kategorizirani radovi koji govore o cenzuri iz povijesnog konteksta, već su oni svrstani u skupinu 1 (Teorija knjižničarstva), postojanje trenda treba tumačiti uz navedeno ograničenje.

Analizom naslova diplomskih radova zaključeno je sljedeće:

Skupina 1. Teorija knjižničarstva. U ovoj skupini nalazimo razne teme, no dvije se među njima ističu. Najveći broj diplomskih radova u skupini 1 bavi se pravnim propisima koji se odnose na knjižničarstvo te na slobodan pristup informacijama. U radovima koji obrađuju pravne propise posebno se uočavaju oni o autorskopravnim pitanjima, sa svega nekoliko onih koji istražuju tu temu u digitalnom okruženju. Radovi o slobodnom pristupu informacijama granaju se u dvije podskupine: radovi koji koriste termin ,slobodan pristup informacijama“ i radovi koji govore o 
cenzuri ${ }^{34} \mathrm{~s}$ različitih gledišta: povijesnog ili recentnog, s naglaskom na knjizi ili na knjižnicama, dok jedan rad govori o autocenzuri. Ostalim radovima koji spadaju u tu kategoriju teško je dati zajednički nazivnik, a samo su neki studenti prionuli istraživanju teorijskih koncepata knjižničarstva. Pravni propisi i slobodan pristup informacijama sigurno jesu važne teme za knjižničare o kojima se mnogo govori u teoriji i praksi te ne čudi velik broj radova navedene tematike.

Skupina 2. Povijest knjižnica, razvoj, knjižnice. Ova skupina okuplja diplomske radove na temu povijesti knjižnica i njihova razvoja te one u kojima autori predstavljaju pojedine knjižnice. Ovdje su predstavljene sve vrste knjižnica, od njihove povijesti pa sve do suvremenih odjela. Velika većina radova očekivano govori o hrvatskim knjižnicama, ali je zanimljiv podatak da su se neki studenti bavili knjižnicama iz Francuske, srednjovjekovne Rusije, Bosne i Hercegovine, u jednom radu tema je bila Aleksandrijska knjižnica, a dva su rada govorila o europskim nacionalnim knjižnicama. Jedan je rad pak govorio o alternativnim informacijskim centrima. Od specijalnih knjižnica koje su se predstavljale, znatan broj govorio je o samostanskim ili crkvenim knjižnicama. Na kraju, ne možemo izostaviti da je uočljiv broj radova na temu multikulturalnosti knjižnica.

Takva se situacija može tumačiti time da studenti izvanrednog studija (studija uz rad) lako i brzo dolaze do podataka o knjižnicama, pa se može pretpostaviti da mnogi radovi iz te skupine pripadaju takvim studentima. Doduše, za točnije tumačenje potrebno je napraviti sveobuhvatnije istraživanje s razdiobom studenata po vrsti studija.

Skupina 3. Nakladništvo, tiskarstvo, povijest knjige. U skupini 3 nalazimo diplomske radove s vrlo raznolikim temama. Većina radova predstavlja hrvatsku nakladničku ili tiskarsku djelatnost, suvremenu i kroz povijest. Tri rada govore o načinu označavanja izdanja u nakladništvu i knjižarstvu (ISSN, ISMN, identifikacijske oznake), dok četiri rada obrađuju temu ilustracija u knjigama. Neočekivano malen broj radova govori o suvremenim trendovima u nakladništvu, pa samo u nekoliko radova nalazimo teme poput elektroničke knjige, tiska na zahtjev i slično. Naposljetku, tek dva rada govore o vezi nakladništva i knjižničarstva.

U ovoj skupini otkriven je negativan trend odabira tema s prosječnim godišnjim smanjenjem broja radova za jedan rad godišnje, odnosno za $16,1 \%{ }^{35}$ (slika 3). S obzirom na mali uzorak, ne mogu se dati konkretni zaključci o linearnom modelu te se oni moraju donositi uz navedeno ograničenje. Dodatno ograničenje postoji i zato što u ovoj skupini nisu navedeni radovi koji se bave cenzurom iz povijesnog konteksta, jer su radovi o cenzuri kategorizirani u skupini 1 (Teorija knjižničarstva) kao radovi na temu slobodnog pristupa informacijama.

${ }^{34}$ U ovome istraživanju radove o cenzuri knjiga stavile smo u skupinu 1 jer smo ih gledale iz perspektive slobodnog pristupa informacijama, a ne iz perspektive povijesti knjige.

35 Formula: $\mathrm{S}=\mathrm{b} /$ prosječni $\mathrm{Y}^{*} 100$. 
Opravdano je pretpostaviti da se postojanje negativnog trenda može tumačiti u svjetlu činjenice da studenti tiskarstvo i nakladništvo vežu uz tisak, a znatno manje uz elektroničke izvore (e-knjige, slobodno dostupna djela i slično).

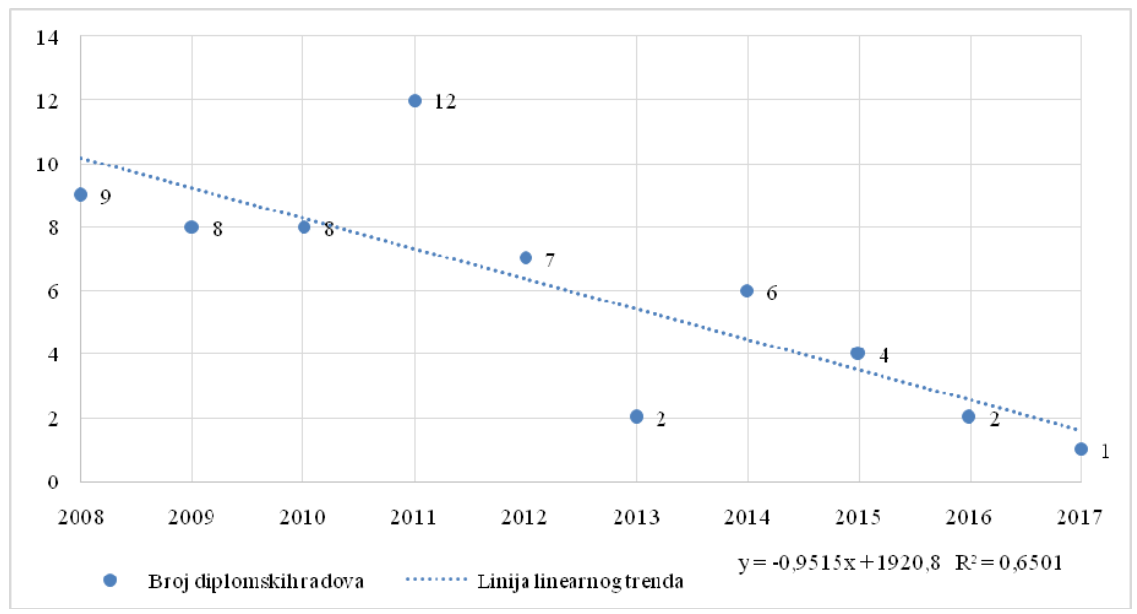

Slika 3. Godišnji broj objavljenih radova za skupinu $3 \mathrm{~s}$ linijom trenda

Skupina 4. Obrazovanje i stalno stručno usavršavanje i Skupina 5. Metodologija istraživanja u knjižničarstvu nemaju diplomskih radova. Prema dobivenim podacima moguće je tumačenje da se u tim dvjema skupinama nalaze teme koje mogu bolje obraditi stručnjaci s više profesionalnog i znanstvenog iskustva, dok studenti vjerojatno smatraju da u dovoljnoj mjeri ne vladaju teorijskim temeljima i nemaju dovoljno iskusan pogled na te dvije tematske skupine.

Skupina 6. Poslovanje i upravljanje. Teme koje su studenti obrađivali u ovoj skupini pokrivaju veći dio poslovanja i upravljanja u knjižnicama. Očekivano, radovi koji govore o opremanju nisu brojni, ali su pokrili mnoge aspekte: od arhitekture do RFID-tehnologije. Desetak radova govori o suradnji među knjižnicama, a skoro trećina radova bavi se nabavom (iz perspektive politika nabave) i zaštitom građe. Mali broj radova govori o djelatnicima knjižnice. Naposljetku, važno je spomenuti da trećina radova govori o marketingu u knjižnicama i u toj podskupini vidimo da su studenti pisali i o uporabi Facebooka kao promidžbenog alata knjižnice. Prema podacima vidljivo je da studenti imaju razvijenu svijest o tome koliko je za knjižnice važno da se otvore prema javnosti i promoviraju svoje usluge kako bi povećale svijest o svojoj važnosti.

Skupina 7. Korisničke službe i aktivnosti knjižnica. Ova skupina ima najveći broj diplomskih radova. Teme koje se u njoj istražuju jesu teme različitih zbirki, odnosno izvora, tiskanih i elektroničkih, a nakon toga slijedi velik broj radova o 
ulozi knjižnice u poduci (informacijska pismenost i ostale vrste pismenosti). Mnogi radovi predstavljaju sve usluge ili većinu usluga neke knjižnice.

Prema dobivenim podacima za ovu skupinu moguće je zaključiti sljedeće: prvo, istraživanje zbirki ili izvora zanima velik broj studenata knjižničarstva, što je očekivano s obzirom na to da knjižnični fond čini temelj poslovanja. U ovoj podskupini radova vidljivo je da je uloga tehnologije važna radi digitalizacije građe te je u njoj najveći broj radova koji istražuju korištenje informacijske i komunikacijske tehnologije u poslovanju knjižnice. Usto, ne može se zaobići vidljiv trend istraživanja zavičajnih, odnosno baštinskih zbirki koje se digitaliziraju te se proces digitalizacije opisuje u diplomskim radovima. Osim teme digitalizacije baštine, studenti istražuju institucijske repozitorije, zbirke e-knjiga i internetske izvore.

Drugo, vidljivo je da studenti prihvaćaju pomak fokusa knjižničarskog posla s građe na korisnika, elaborirajući suvremenu ulogu knjižnice u svim oblicima obrazovanja korisnika (formalnim, neformalnim i informalnim). Posebno se izdvaja velik broj radova o ulozi knjižnice u formalnom obrazovnom procesu. Dakako, najveći broj radova koji se bave uključivanjem knjižnica u obrazovni proces obrađuje tu temu na primjeru školskih knjižničara. Možemo pretpostaviti da se među studentima koji studiraju izvanredno nalazi velik broj knjižničara koji rade u školskim knjižnicama i osobno su zainteresirani za problematiku dobre suradnje školske knjižnice sa školom te tu preokupaciju izražavaju kroz diplomski rad.

Skupina 8. Obrada, sustavi za označivanje i pretraživanje. U ovoj skupini ravnomjerno su raspoređeni radovi prema navedenim podskupinama, odnosno trećina radova bavi se metapodacima i katalozima, trećina formalnom obradom, a trećina sadržajnom i predmetnom obradom. Nalazimo dva rada koji se bave modelom FRBR, što pokazuje interes studenata za razvoj toga aspekta knjižničarstva. Na kraju, bez obzira na posvemašnje korištenje Weba 2.0. i društvenih medija, tek dva diplomska rada bavila su se korisničkim označivanjem sadržaja, iako bi se mogao očekivati veći broj takvih tema.

Skupina 9. Korisničke potrebe i informacijsko ponašanje. Dvije trećine radova u ovoj skupini odnose se na istraživanja korisničkog informacijskog ponašanja, s naglaskom na navikama čitanja, no nailazimo i na radove u kojima se istražuje informacijska pismenost korisnika. U jednoj trećini radova nalazimo raznovrsne teme, poput korisničkog vrednovanja usluga ili izvora, ali je naglasak opet stavljen na čitanje. U toj skupini nalazimo radove koji se bave medijima i elektroničkim izvorima podataka, a ne samo tiskanima, no u manjini.

I radovi u toj skupini pokazuju relativno tradicionalan pristup studenata knjižničarskim temama, s naglaskom na čitanju i tiskanim izvorima.

Skupina 10. Znanstvena i profesionalna komunikacija. Ova skupina broji tek sedam radova na temu znanstvenih časopisa, znanstvene produkcije i citatnih analiza, a zbog njihove raznorodnosti nije bilo moguće izvući određenije zaključke. 
Skupina 11. Ostale teme. U ovoj skupini nalazimo radove vrlo raznovrsnih tema, s naglaskom na temama iz drugih grana informacijskih i komunikacijskih znanosti (leksikografija i enciklopedistika, muzeologija, organizacija i informatika), no zastupljene su i teme iz drugih znanstvenih polja (filologija, posebice književnost). Upada u oči skupina radova koja se bavi percepcijom knjižnica u popularnoj kulturi, filmu ili književnim djelima.

Analiza sadržaja diplomskih radova sa studija Informacijskih znanosti, smjer bibliotekarstvo na Odsjeku za informacijske i komunikacijske znanosti pri Filozofskom fakultetu Sveučilišta u Zagrebu nudi nam sljedeći zaključak: ako okolinu i knjižničarske poslove dijelimo na tradicionalne i netradicionalne, možemo reći da studenti većinom poimaju knjižničarstvo kroz tradicionalne poslove u tradicionalnom okruženju. Prema Machali ${ }^{36}$, tradicionalna okolina sinonim je za knjižnicu kao mjesto rada, dok se netradicionalnom okolinom smatraju knjižničarska radna mjesta u institucijama obrazovanja, poslovnim tvrtkama, javnim i vladinim agencijama. Tradicionalni se poslovi „odnose na primjenu znanja, vještina i sposobnosti usvojenih kroz programe obrazovanja za struku“. Najveći broj radova tako govori o tradicionalnim poslovima u tradicionalnoj okolini. No izdvaja se poveći broj radova kojima studenti problematiziraju tradicionalni posao u netradicionalnoj okolini kroz sudjelovanje knjižnice $u$ formalnom obrazovnom procesu. O ostalim tradicionalnim poslovima u netradicionalnoj okolini, poput uklopljenog knjižničarstva, studenti uopće ne pišu. Interes da pišu o netradicionalnim poslovima u tradicionalnoj ili netradicionalnoj okolini (npr. sistemski knjižničari, digitalni knjižničari, knjižničari u području e-znanosti i e-obrazovanja, knjižničari za metapodatke ili istraživačke podatke...) studenti kroz diplomske radove ne iskazuju.

Nadalje, osim korištenja tehnologije za digitalizaciju i očuvanje zbirki, studenti ne stavljaju osobit naglasak na sve druge aspekte tehnologije u knjižnicama, poput autorskopravnih pitanja vezanih uz e-zbirke ili korištenje tehnologije u poduci na daljinu ili internoj organizaciji znanja, nego tek prepoznaju važnost društvenih medija u marketingu i odnosima s javnošću.

\section{Zaključak}

Rezultati ovoga istraživanja pokazali su da postoji nejednaka distribucija radova prema temama diplomskih radova. Najzastupljenije su teme o uslugama i aktivnostima knjižnice, dok su teme o metodologiji i obrazovanju u knjižničarstvu potpuno zaobiđene. Podzastupljene su teme iz znanstvene komunikacije te obrade i sustava za označivanje i pretraživanje. U istraženom desetogodišnjem razdoblju vidljiv je negativan linearni trend odabira tema iz skupine 3 (Nakladništvo, tiskar-

36 Machala, D. Knjižničarske kompetencije : pogled na razvoj profesije. Zagreb: Hrvatska sveučilišna naklada : Nacionalna i sveučilišna knjižnica u Zagrebu, 2015. Str. 274-276. 
stvo, povijest knjige), dok u ostalim skupinama nije uočen linearni trend odabira tema.

Analiza naslova omogućila je dublji uvid u teme koje zanimaju studente. Nameće se zaključak da studente još uvijek više zanimaju tradicionalni poslovi u tradicionalnoj okolini, dok manje istražuju tradicionalne poslove u netradicionalnoj okolini te netradicionalne poslove u tradicionalnoj i netradicionalnoj okolini, a prema Machalinoj definiciji tradicionalnih i netradicionalnih poslova i okoline. ${ }^{37}$

Dodatni doprinos ovoga rada svakako je i klasifikacijska shema istraživačkih tema razdijeljenih u 11 skupina. Temelj te razdiobe tema leži u klasifikacijskoj shemi Järvelina i Vakkarija iz 80-ih godina 20. stoljeća. S obzirom na dokumentirane primjedbe na tu shemu i provedeno testno kodiranje, za potrebe ovog istraživanja stvorena je dopunjena i izmijenjena shema za koju smatramo da prati recentne trendove u knjižničarstvu. Ta klasifikacijska shema može biti temelj za daljnja istraživanja na temu organizacije znanja u informacijskim znanostima te knjižničarstvu.

Ovo istraživanje ima određena metodološka ograničenja: (a) nije bilo moguće utvrditi zastupljenost tema prema različitim obilježjima studenata, odnosno prema tipu studija (redovni, izvanredni, dodatni, bolonjski, predbolonjski); (b) s obzirom na to da je rađena analiza naslova (iznimno uvidom u sam tekst rada), za pojedine radove nije bilo moguće napraviti precizno određenje teme; (c) radovi su kategorizirani prema glavnoj temi, iako se u pojedinim radovima obrađivalo više tema. S obzirom na njih, preporučuje se dodatnim istraživanjima ustvrditi zastupljenost tema prema različitim obilježjima studenata te preciznije kategorizirati teme.

Budućim studentima rezultati ovog istraživanja mogu biti polazišna točka pri odabiru teme za diplomski rad. Ujedno mogu biti smjerokaz i istraživačima i nastavnicima, odnosno mentorima na diplomskim radovima.

\section{LITERATURA}

Anna, N. E. V.; E. F. Mannan; D. P. Srirahayu; F. Mutiai. Library and information (LIS) research topics in Indonesia from 2006 to 2017. // Library Philosophy and Practice. 2018. [citirano 2018-08-30]. Dostupno na: http://digitalcommons.unl.edu/libphilprac/1773/.

Bačić, M.; Z. Majstorović. Kvantitativna raščlamba članaka objavljenih u Vjesniku bibliotekara Hrvatske. // Vjesnik Bibliotekara Hrvatske 50, 4(2007), 15-25. Dostupno i na: https://hrcak.srce.hr/85586 [citirano 2018-08-30].

37 Isto. 
Barbarić, A. Popis diplomiranih studenata na Dodiplomskom studiju bibliotekarstva Filozofskog fakulteta u Zagrebu 2007.-2008. // Vjesnik bibliotekara Hrvatske 51, 1-4(2008), 287-289. Dostupno i na: https://hrcak.srce.hr/85679 [citirano 2018-0830].

Barbarić, A. Popis diplomiranih studenata na Izvanrednom studiju bibliotekarstva Filozofskog fakulteta u Zagrebu 2007.-2008. // Vjesnik bibliotekara Hrvatske 51, 1-4(2008), 292-297. Dostupno i na: https://hrcak.srce.hr/85681 [citirano 2018-0830].

Barbarić, A. Popis obranjenih diplomskih radnji na Studiju informatologije, smjer bibliotekarstvo Filozofskog fakulteta u Zagrebu 2007.-2008. // Vjesnik bibliotekara Hrvatske 51, 1-4(2008), 290-291. Dostupno i na: https://hrcak.srce.hr/85680 [citirano 2018-08-30].

Barbarić, A.; I. Hebrang Grgić; A. Horvat. Metodološki i sadržajni aspekti znanstveno istraživačkih radova objavljenih u Vjesniku bibliotekara Hrvatske od 1998. do 2006. godine. // Vjesnik Bibliotekara Hrvatske 50, 4(2007), 1-14. Dostupno i na: http:// www.hkdrustvo.hr/vbh-arhiva/broj/97 [citirano 2018-08-31].

Blessinger, K.; M. Fraiser. Analysis of a decade in library literature: 1994-2004. // College \& Research Libraries 68, 2(2007), 155-169. DOI: 10.5860/crl.68.2.155.

Crumley, E.; D. Koufogiannakis. Developing evidence-based librarianship: practical steps for implemantation. // Health Information and Libraries Journal 19, 2(2002), 61-70. DOI: 10.1046/j.1471-1842.2002.00372.x.

ECTS informacijski paket za akademsku godinu 2018/2019. [citirano 2018-10-30]. Dostupno na: http://theta.ffzg.hr/ECTS/Studij/Lista?razinaStudijaID=4.

Hebrang Grgić, I. ; A. Barbarić. LIS student's diploma theses as digital documents : citation analysis. // La médiation numérique : renouvellement et diversification des pratiques / ed. by Boustany, J.; E. Broudoux ; G. Chartron. Bruxelles: De Boeck, 2014. Str. 183-190.

Hebrang Grgić, I. Popis diplomiranih studenata na studiju bibliotekarstva na Filozofskom fakultetu u Zagrebu. // Vjesnik bibliotekara Hrvatske 53, 3-4(2010), 243-247. Dostupno i na: https://hrcak.srce.hr/80609 [citirano 2018-08-30].

Hebrang Grgić, I. Popis obranjenih diplomskih radova na dodiplomskom studiju bibliotekarstva, studiju informatologije (smjer bibliotekarstvo) i izvanrednom studiju bibliotekarstva na Filozofskom fakultetu u Zagrebu 2011. godine. // Vjesnik bibliotekara Hrvatske 56, 1-2(2013), 386-392. Dostupno i na: https://hrcak.srce.hr/115670 [citirano 2018-08-30].

Järvelin, K; P. Vakkari. Content analysis of research articles in library and information science. // Library and Information Science Research, 12(1990), 395-421.

Järvelin, K; P. Vakkari. The evolution of Library and information science 1965-1985: a content analysis of journal articles. //Information Processing and Management 29, 1(1993), 129-144. DOI: 10.1016/0306-4573(93)90028-C. 
Koufogiannakis, D.; L. Slater; E. Crumley. A content analysis of Librarianship research. // Journal of Information Science 30, 3(2004), 227-239. DOI: $10.1177 / 0165551504044668$.

Machala, D. Knjižničarske kompetencije : pogled na razvoj profesije. Zagreb: Hrvatska sveučilišna naklada: Nacionalna i sveučilišna knjižnica u Zagrebu, 2015.

Natječaj/upis na izvanredni studij informacijskih znanosti (bibliotekarstvo). [citirano: 2018-10-30]. Dostupno na: http://inf.ffzg.unizg.hr/index.php/hr/studij/izvanredni-studij-novi/natjecaj-upis.

Paul-Hus, A.; P. Mongeon; F. Shu. Portraying the landscape of Canadian library and information science research. // Canadian Journal of Information and Library Science 40, 4(2016), 332-346. citirano [2018-08-30]. Dostupno na: https://muse.jhu.edu/ article/649274.

Pravilnik o znanstvenim i umjetničkim područjima, poljima i granama. // Narodne novine 118, 2929(2009). [citirano 2018-08-28] Dostupno na: https://narodne-novine. nn.hr/clanci/sluzbeni/2009_09_118_2929.html.

Prebor.G. Information science - facing social and ethical challenges: analysis of masters' theses and doctoral dissertations over the past five years (2002-2006) in Information science departments worldwide. // Journal of Information, Communication and Ethics in Society 5, 2/3(2007), 253-269. DOI: 10.1108/14779960710837687.

Repozitorij Filozofskog fakulteta u Zagrebu. [citirano:2018-11-21]. Dostupno na http:// darhiv.ffzg.unizg.hr/.

Rochester, M.; P. Vakkari. International Library and information science research: a comparison of national trends. [Haag]: International Federation of Library Associations and Institutions, cop. 2003. (IFLA professional reports ; nr.82). [citirano 201808-30]. Dostupno na: https://www.ifla.org/publications/ifla-professional-reports-82.

Shu, F.; J. Beheshti. The landscape of LIS research and teaching area: iSchools versus non-iSchools in North America. // iConference Proceedings, 2016. 1-7. DOI: 10.9776/16203.

Tot, M.; I. Hebrang Grgić; A. Barbarić. Popis studenata koji su obranili diplomski rad na diplomskom studiju informacijskih znanosti, smjer bibliotekarstvo na Odsjeku za informacijske i komunikacijske znanosti Filozofskog fakulteta Sveučilišta u Zagrebu (reformirani, tzv. bolonjski studij, redovni i izvanredni način studiranja) 2013. godine. // Vjesnik Bibliotekara Hrvatske 58, 1-2(2015), 440-445. Dostupno i na: https:/hrcak.srce.hr/143661 [citirano 2018-08-30].

Tot; M.; I. Hebrang Grgić; A. Barbarić. Popis studenata koji su obranili diplomski rad na diplomskom studiju informacijskih znanosti, smjer bibliotekarstvo na Odsjeku za informacijske i komunikacijske znanosti Filozofskog fakulteta Sveučilišta u Zagrebu (reformirani, tzv. bolonjski studij, redovni i izvanredni način studiranja) 2014. godine. // Vjesnik Bibliotekara Hrvatske 58, 1-2(2015), 446-450. Dostupno i na: https:/hrcak.srce.hr/143662 [citirano 2018-08-30]. 
Tuđman, M.; M. Milas; N. Tudor-Šilović; D. Boras. Bibliometric analysis of master theses in Information sciences (postgraduate studies in Librarianship, Archivistics, Museology and Information sciences, 1961-1964, Zagreb, Yugoslavia). // Education for Information 3, 4(1985), 291-306. DOI: 10.3233/EFI-1985-3404.

Tuomaala, O.; K. Järvelin; P. Vakkari. Evolution of Library And information science, 1965-2005: content analysis of journal articles. // Journal of the Association for Information Science and Technology 65, 7(2014), 1446-1462. DOI: https://doi. org/10.1002/asi.23034.

Vukasović, K. Teme doktorskih disertacija iz bibliotekarstva i informacionih nauka objedinjene na univerzitetima u Jugoslaviji. // Naučna istraživanja u bibliotekarstvu: zbornik radova s Trećeg jugoslavenskog interkatedarskog skupa nastavnika bibliotekarstva. Beograd: Filološki fakultet, 1988. Str. 37-44.

Wilson, T. D. Mapping the curriculum in information studies. // New Library World 102, 11/12(2001), 436-442. DOI: https://doi.org/10.1108/03074800110411875.

Yi, K.; R. Turner. The current landscape of the school librarianship curricula in USA. // Journal of Education for Library and Information Science 55, 4(2014), 303-321. [citirano 2018-08-30]. Dostupno na: https://eric.ed.gov/?id=EJ1074323.

Zins, C. Classification schemes of Information science: twenty-eight scholars map the field. // Journal of the American Society for Information Science and Technology 58, 5(2007), 645-672. DOI: https://doi.org/10.1002/asi.20506.

Zins, C. Knowledge mapping research. // Journal of the American Society for Information Science and Technology 58, 4(2007), 526-535. DOI: 10.1002/asi.v58:4. 